\title{
ESTIMATION OF SHIP DOMAIN ZONE
}

\section{ABSTRACT}

The paper discusses the ship domain zone or ship navigation safety area. The navigation safety area around the ship has been the object of research of many authors. Different variants and algorithms have been suggested and the most popular among them are as follows:

- navigation safety area around the ship being observed by her own devices, presenting information of the danger of possible collision directly on the bridge;

- navigation safety area around the ship when regulating her movement by means of Vessel Traffic Services.

The article presents an algorithm for determination and plotting of the navigation safety area, which has the following advantages:

- the algorithms give an instant solution to the problem of evading one or more dangerously moving targets;

- the calculation may apply the ARPA (Automatic Radar Plotting Aids) algorithm, which does not prevent the navigator from keeping watch.

The above mentioned algorithm allows simultaneous plotting of information about the situation around the ship and the data for probable manoeuvring.

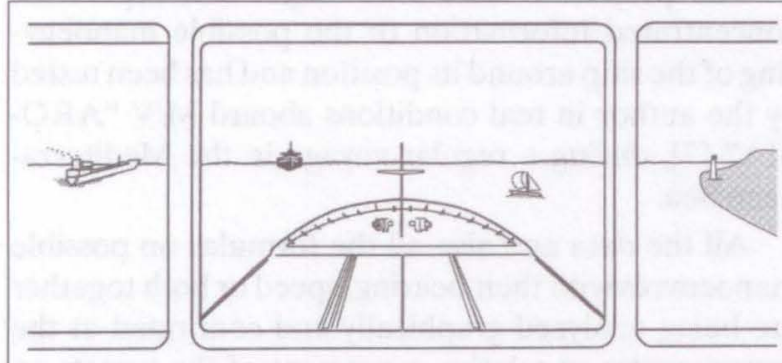

Course ref.: $360^{\circ}$ - Ships HDG: $240^{\circ}$-range: $6 \mathrm{NM}$ - Vector: $12 \mathrm{~min}$

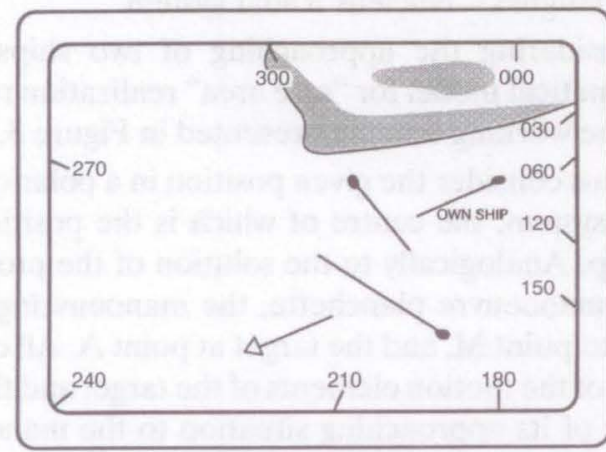

Figure 1 - Radar screen:

TRUE MOTION - TRUE VECTOR - NORTH UP

\section{KEY WORDS}

safety of navigation, ARPA, ship domain zone, avoidance of the collision at sea

\section{INTRODUCTION}

The visualization of radar information has been significantly developed during the years of information and technological progress. The perfection of radars, the increase of their "intellectual" possibilities permitted a large part of the information to be shown on the display graphically, which facilitates control decision-making on the ship bridge. Radar plotting is a graphical display of the movements of objects observed on the radar screen and plotted on the radar diagram.

Observing the relative vector one can see that the collision situation takes place when the relative vector passes through the ship itself or the centre of the radar screen.

Radar plotting is used to:

- avoid collisions at sea during voyage by altering one's own ship course only;

- avoid collisions at sea during voyage by altering one's own ship speed only;

- avoid collisions at sea during voyage by altering one's own ship course and speed;

- calculate the course (Kt) and speed (bt) of the observed target vessel;

predict manoeuvres of the observed ships.

Two types of radar plotting are distinguished:

- relative, and

- absolute.

When observing targets on the radar screen we are not interested only in their movement relative to one's own ship, but also their movement relative to each other. However, if we know the distance of their passing, we can anticipate their possible alteration of the course or speed, which may affect our future manoeuvre [1].

The avoidance manoeuvre at a definite CPA (Closest Point of Approach) should be carried out early enough. The closer to the CPA circle the APT 
(Action Point Time) is located, the major alteration of course is necessary to pass the target at a definite distance. The necessary course alteration can reach up to $90^{\circ}$, which, however, is not supported by some ARPA or simulator software, and in such case the entire system is blocked.

From this, two conclusions can be drawn:

- avoidance manoeuvre for a relevant CPA must start on time,

- if the observed target approaches too close to the CPA circle, the CPA condition should be reduced.

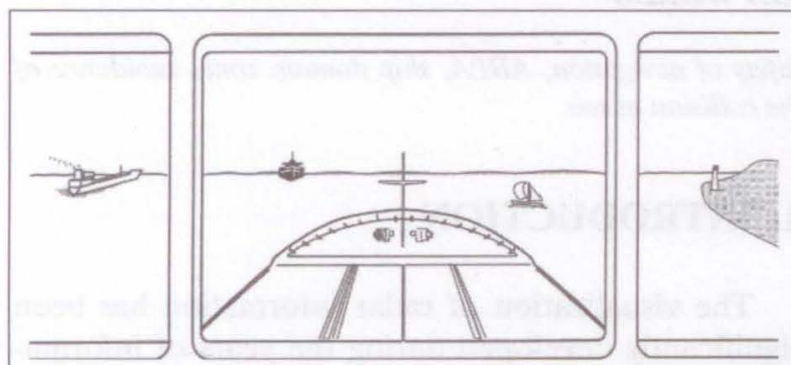

Course ref:: $360^{\circ}$ - Ships HDG: $240^{\circ}$-range: $6 \mathrm{NM}$ - Vector: $12 \mathrm{~min}$

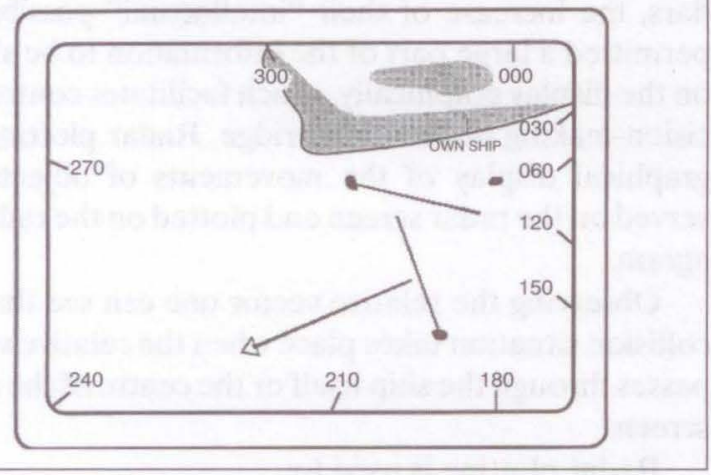

Figure 2 - Radar screen:

TRUE MOTION - RELATIVE VECTOR - NORTH UP

The Automatic Radar Plotting Aids (ARPA) system incorporates the technological development and the aim to eliminate the subjective factor as error source. The theories of a Safe Navigation Area "Domain Zone" (DZ) around the ship and its display on ARPA provide the way for the realization of these objectives.

\section{EXISTING ALGORITHMS OF A SHIP DOMAIN}

The idea for fast and exact transfer of navigation information, reflecting the safe motion of the ship on the grounds of its manoeuvring characteristics, is incorporated in the creation and implementation of DZ in the shore Vessel Traffic Services (VTS) [2, 3, 4]. Depending on the scope of research, the following concepts are considered: "Collision Region", "Evasion Area" and "Domain Zone" $[5,6]$.
For the navigation practice, greater interest is on the concept, giving possibility for independent solutions, i. e. creation of DZ around the ship, which can be surveyed by the bridge navigation technology, in this case - ARPA. Such idea has been realized by SPERRY Co. and is known as "Predicted Area of Danger" [6]. For the graphic display of the area the values of the motion elements of one's own ship and the target, and the set safe passing distance are used.

Another concept in the literature [6, 7] realizes an area around the ship, the size of which depends on various factors, most important of which are: the human factor/training, the ship dimensions and type, the sailing conditions, the relative speed of the approaching objects, the sea traffic density, etc. Depending on these factors the navigator is given a DZ, presented on the radar screen as sections of various dimensions [7].

The above concepts have a major shortcoming: to make a decision on a manoeuvre, the navigator has to exit the ARPA working mode and turn to "Trial Manoeuvre" mode, which distracts him from the real conditions around the ship for a time $[5,7]$.

The mathematical model proposed herein gives the possibility, with suitable software, for the sections of safe manoeuvring of the ship to be presented on an external device monitor or the ARPA screen.

\section{MATHEMATICAL MODEL OF A SHIP DOMAIN}

The proposed "safe area" algorithm represents concentrated information of the possible manoeuvring of the ship around its position and has been tested by the author in real conditions aboard M/V "AROSIA" [7], during a regular voyage in the Mediterranean Sea.

All the data and also all the formulas on possible manoeuvres with their bearing, speed or both together are being analyzed graphically and confirmed at the screen centre at relative movement of the targets on Kelvin Hughes - Nucleus Radar system.

Considering the approaching of two ships, the mathematical model for "safe area" realization represents the working scheme presented in Figure 3.

Let us consider the given position in a polar co-ordinate system, the centre of which is the position of our ship. Analogically to the solution of the problem with a manoeuvre planchette, the manoeuvring ship will be at point $\mathrm{M}$, and the target at point $\mathrm{A}$. All calculations of the motion elements of the target and the elements of its approaching situation to the manoeuvring ship are made on the $\mathrm{ABH}$ triangle. In this case it is necessary to determine the location of point $\mathrm{H}$ towards point $\mathrm{M}$. 


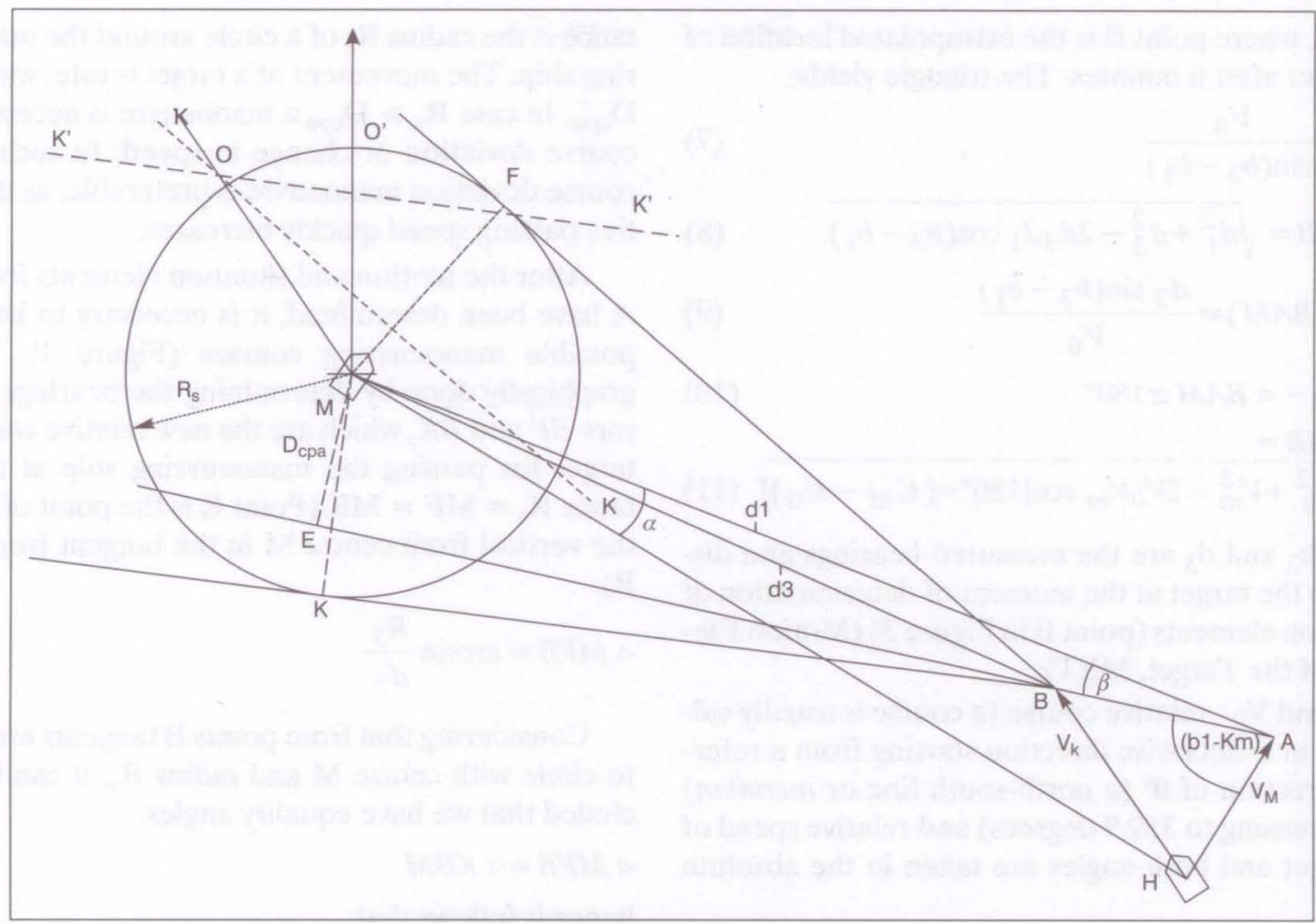

Figure 3 - The sketch of mathematical model for "safe area"

Where: $\overrightarrow{A B}$ - relative vector of target ship;

$\overrightarrow{H B}$ - true vector of target ship;

$\overrightarrow{H A}$ - relative vector of one's own ship.

After ARPA has located the target, the bearing is ordinarily calculated in a clockwise direction starting from a reference direction of $0^{\circ}$ and increasing to 359.9 degrees. Measured in this way the bearing is referred to as an azimuth in maritime or aircraft navigation. An angle may be measured from straight ahead on each side. If the reference direction is straight ahead, then the bearing is called a relative bearing. Starboard bearings are "green" and port bearings are "red" - in mathematical calculation thus green gets a positive and red gets a negative sign. $\omega_{\mathrm{MA}}=b_{1}$ and distance $\mathrm{MA}=d_{1}$ are automatically determined. The MAH triangle is considered, where $\overrightarrow{H A}=\overrightarrow{V_{M}}$ - length of the vector is speed of one's own ship, $\mathrm{K}_{\mathrm{M}}$ - direction of the vector $\overrightarrow{H A}$ starting from the North or $000^{\circ}$ is the course of one's own ship.

A precondition is for the ship speed vectors to be six-minutes, as in this way the speed and distance scales are equalized.

$H A=360 \cdot V_{S}$

where: $V_{\mathrm{S}}$ is speed of one's own ship.

The distance $\mathrm{MH}$ and $\omega_{\mathrm{MH}}$ in the $\mathrm{AMH}$ triangle yields:

$\frac{\sin \alpha}{V_{M}}=\frac{\sin \left(b_{1}-K_{M}\right)}{|M H|}$

$\sin \alpha=V_{M} \frac{\sin \left(b_{1}-K_{M}\right)}{|M H|}$ $\alpha=\arcsin \left[\frac{V_{M}}{|M H|} \sin \left(b_{1}-K_{M}\right)\right]$

Through Figure 1 formulas (2) and (3) can be explained; first of all, formula (2). The exact form of a formula that meets the definition of points in the preceding paragraph in Figure 3 to read:

$M H=\sqrt{V_{m}^{2}+d_{1}^{2}-2 V_{M} d_{1} \cos \left(b_{1}-K_{M}\right)}$

and represents the use of cosines sentence on the triangle AMH. The following formulas represent the use of sinus sentence on the same triangle and calculate the angle under which from the point of M you can see point (object) $\mathrm{N}$, indicated in Figure 3 as $\alpha$.

$\omega_{M H}=b_{1}+\arcsin \left[\frac{V_{M} \sin \left(b_{1}-K_{M}\right)}{M H}\right]$

where: $b_{1}$ and $d_{1}$ are the measured bearings. In maritime navigation, a bearing is the direction of one object from another object, usually, the direction of an object from one's own vessel. In aircraft navigation, a bearing is the actual (corrected) compass direction of the forward course of the aircraft. In land navigation, a bearing is the angle between a line connecting two points and a north-south line (or meridian) and distance to the target at the initial point (point $\mathrm{A}$ in Figure 3 ) of its location by ARPA.

In this way the location of point $\mathrm{M}$ is exactly determined. This gives the possibility to consider the MAB 
triangle, where point $\mathrm{B}$ is the extrapolated location of the target after 6 minutes. The triangle yields:

$$
\begin{aligned}
& \frac{d_{3}}{\sin \beta}=\frac{V_{0}}{\sin \left(b_{3}-b_{1}\right)} \\
& V_{0}=A B=\sqrt{d_{1}^{2}+d_{3}^{2}-2 d_{3} d_{1} \cos \left(b_{3}-b_{1}\right)} \\
& \sin \beta(\triangleleft B A M)=\frac{d_{3} \sin \left(b_{3}-b_{1}\right)}{V_{0}} \\
& K_{0}=b_{1}-\triangleleft B A M \pm 180^{\circ} \\
& V_{K}=H B= \\
& =\sqrt{V_{0}^{2}+V_{m}^{2}-2 V_{0} V_{m} \cos \left[180^{\circ}-\left(K_{M}-K_{0}\right)\right]}
\end{aligned}
$$

where: $b_{3}$ and $d_{3}$ are the measured bearings and distance to the target at the moment of determination of its motion elements (point B in Figure 3) (Motion Elements of the Target, MET);

$\mathrm{K}_{0}$ and $\mathrm{V}_{0}$ - relative course (a course is usually calculated in a clockwise direction starting from a reference direction of $0^{\circ}$ (a north-south line or meridian) and increasing to 359.9 degrees) and relative speed of the target and both angles are taken in the absolute value.

From the MBE triangle one may determine the shortest distance $\mathrm{D}_{\mathrm{cpa}}$, at which the manoeuvring ship will pass the target:

$$
D_{c p a}=d_{3} \sin \left[180^{\circ}+\left(b_{3}-K_{0}\right)\right]
$$

The requirements to moving and standing objects passing distances vary in the different sailing areas. In the suggested "safe area" mode the set passing dis- tance is the radius $R_{\mathrm{s}}$ of a circle around the manoeuvring ship. The movement of a target is safe, when $R_{\mathrm{s}}$ ? $D_{\text {cpa. }}$. In case $R_{s}>D_{\text {cpa }}$ a manoeuvre is necessary for course deviation or change in speed. In such case a course deviation manoeuvre is preferable, as the relative passing speed quickly increases.

After the motion and situation elements for target A have been determined, it is necessary to know the possible manoeuvring courses (Figure 4). This is graphically done by determining the bearings of vectors $\overrightarrow{B F}$ and $\overrightarrow{B K}$, which are the new relative courses of target for passing the manoeuvring ship at the distance $\mathrm{R}_{\mathrm{s}}=\mathrm{MF}=\mathrm{MK}$ (Point $\mathrm{K}$ is the point of cutting the vertical from centre $\mathrm{M}$ in the tangent from point B).

$$
\triangleleft M F B=\arcsin \frac{R_{S}}{d_{3}}
$$

Considering that from points $\mathrm{B}$ tangents are drawn to circle with centre $M$ and radius $R_{s}$, it can be concluded that we have equality angles:

$\triangleleft M F B=\triangleleft K B M$

hence it follows that:

$2 \triangleleft M F B=\triangleleft K B F$

In this way the problem for determining the dangerous sections is reduced to finding the value of angle $\mathrm{KBF}$ :

$\triangleleft K B F=2 \arcsin \frac{R_{S}}{d_{3}}$

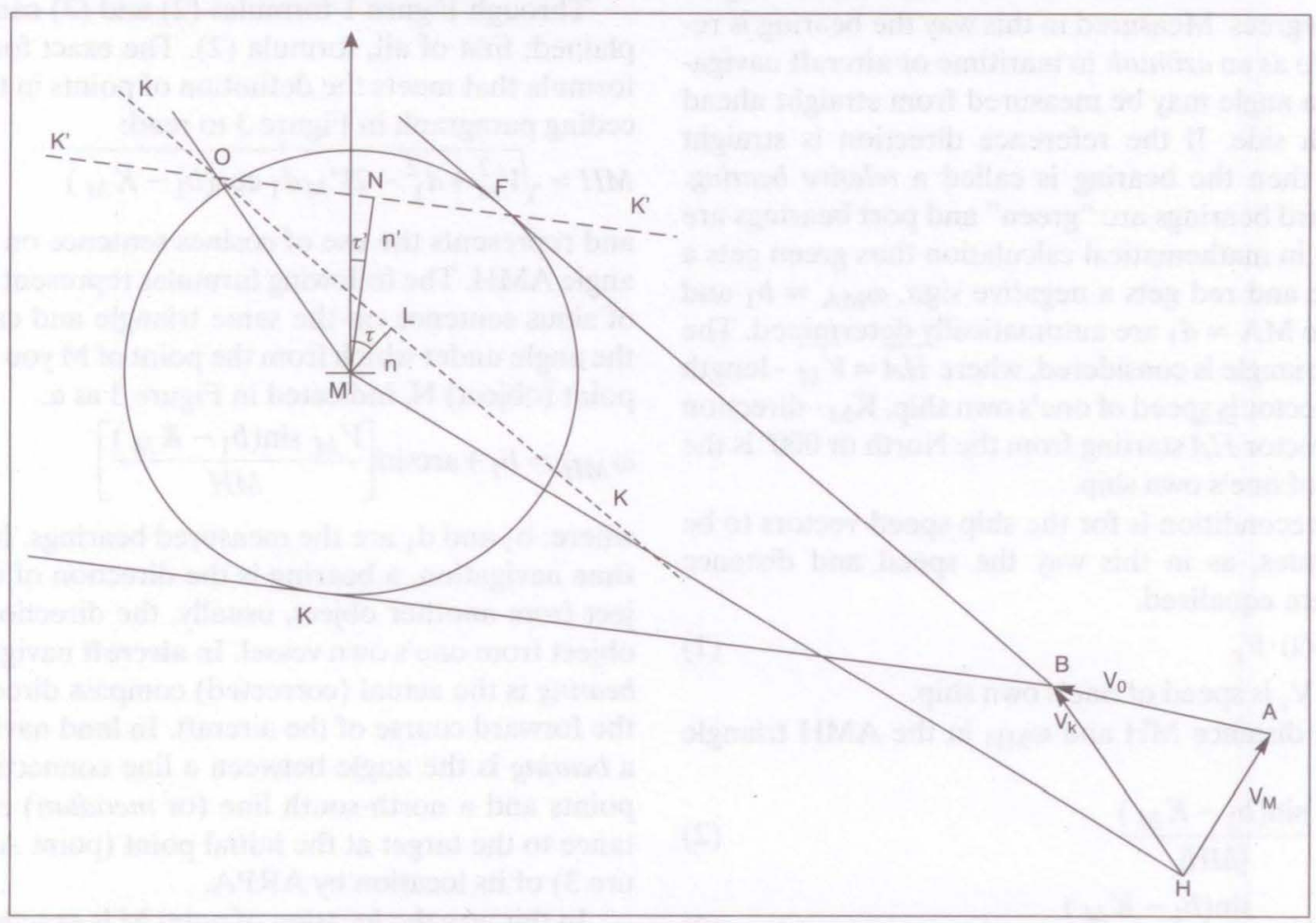

Figure 4 - The sketch of possible manoeuvring courses 
This angle, carried at the end of vector $\overrightarrow{V_{K}}$ with arms parallel to vectors $\overrightarrow{B F}$ and $\overrightarrow{B K}$, crosses the circle with radius $V_{M}$ and centre point $M$ in points, which outline a section of dangerous courses, when connected with $\mathrm{M}$. The following is obtained for vector $\overrightarrow{V_{K}}$ from Figures 4 and 5: $\overrightarrow{V_{K}}=\overrightarrow{H B}=\overrightarrow{M O}$ (vector $\overrightarrow{H B}$ transferring from point $\mathrm{H}$ to $\mathrm{M}$ ).

The arms of angle KBF are plotted by determining the elements of the straight lines KK and K'K':

- the angles $\tau$ and $\tau^{6}$;

- the carries of $\mathrm{n}$ and $\mathrm{n}$;

To determine $\tau$ and $\mathrm{n}$ of the straight line KK the triangle MFB is considered, where the direction MB $=B_{3}$ is known. The following is obtained for angle MFB:

$\triangleleft M F B=\arcsin \frac{R_{S}}{d_{3}}$

Then the following is obtained for the direction from point $\mathrm{M}$ to point $\mathrm{F}$ :

$\overrightarrow{M F}=b_{3}-\triangleleft M F B$

The value of angle $\tau$ in a ring system coincides with the MF direction:

$\tau=b_{3}-\arcsin \frac{R_{S}}{d_{3}}$

To determine the $n$ carry value, triangle $M O L$ is considered, where $\tau$ and $K_{k}$ are known. $K_{k}$ is the course of ship target and obtained from plotting or radar.

Therefore, angle OMF will be equal to $\tau+K_{k}$, so the following is obtained for the carry:

$n=V_{K} \cos \left(\tau-K_{K}\right)$

In this way the straight line $\mathrm{KK}$ is determined. Analogically, the elements of the straight line K'K' are obtained:

$\left\{\begin{array}{l}\tau^{\prime}=b_{3}+\arcsin \frac{R_{S}}{d_{3}} \pm 180^{\circ} \\ n^{\prime}=V_{K} \cos \left(\tau^{\prime}-K_{K}\right)\end{array}\right.$

Thus the new lines of relative movement (LRM) at a changing course manoeuvre to the left or right are determined. They pass through the vertex of vector $V_{k}$ and pass a circle with radius $R=V_{M}$.

To determine the crossing points, the following equation is used:

$X^{2}+Y^{2}=R^{2}$

where $R=V_{M}$ is the radius of the circle around the screen centre.

A two-equation system is composed as follows:

$X^{2}+Y^{2}=V_{M}^{2}$

$X \sin \tau+Y \cos \tau-n=0$

The second equation of the system is the equation of the KK straight line, representing LRM.
Upon processing of the equations of (23), a quadratic equation is obtained, with discriminant $\mathrm{D}$ :

$D=\sin ^{2} \tau\left(V_{M}^{2}-n^{2}\right)$

The roots of the quadratic equation are co-ordinates of the points in which KK cross the circle with radius $\mathrm{V}_{\mathrm{M}}$.

$X_{1}=n \sin \tau+\sqrt{D}$

$Y_{1}=\frac{n-\sin \tau X_{1}}{\cos \tau}$

$X_{2}=n \sin \tau+\sqrt{D}$

$Y_{2}=\frac{n-\sin \tau X_{2}}{\cos \tau}$

To obtain the crossing points of the straight line K'K' and the circle with radius $V_{m}$ the second equation in (23) is replaced with the equation, containing the K'K' elements.

Then (23) looks as follows:

$\mid \begin{aligned} & X^{2}+Y^{2}=V_{M}^{2} \\ & \sin \tau^{\prime} X+\cos \tau^{\prime} Y-n^{\prime}=0\end{aligned}$

The solutions of system (27) are:

$X_{1}^{\prime}=n^{\prime} \sin \tau^{\prime}+\sqrt{D}$
$Y_{1}^{\prime}=\frac{n^{\prime}-\sin \tau^{\prime} X_{1}}{\cos \tau^{\prime}}$

and

$X_{2}^{\prime}=n^{\prime} \sin \tau^{\prime}+\sqrt{D}$
$Y_{2}^{\prime}=\frac{n^{\prime}-\sin \tau^{\prime} X^{\prime}}{\cos \tau^{\prime}}$

where $D^{\prime}=\sin ^{2} \tau^{6}\left(V_{M^{2}-n^{\prime 2}}\right)$ is the discriminant of the quadratic equation, obtained upon processing of the system (27).

In a general case, depending on the course angles of our ship and the target, LRM will cross the circle in four points, which, connected with the centre, will draw the section of dangerous courses (Figure 5).

\section{CONCLUSION}

The proposed mathematical model, describing the domain zone around the ship or navigation safety area (NSA), is easy for software application in any electronic radar device. It gives the possibility to reduce the time for evaluation of the situation around the ship and to take an adequate decision. It completes the available models and allows compatibility of radio location and graphic imaging on the same screen.

The current paper aims at working out a safe and controlled collision avoidance manoeuvre, which complies with the Collision Avoidance Rules and is efficiently applied in navigation at sea. It also aims at enhancing the safety of merchant shipping in general. 


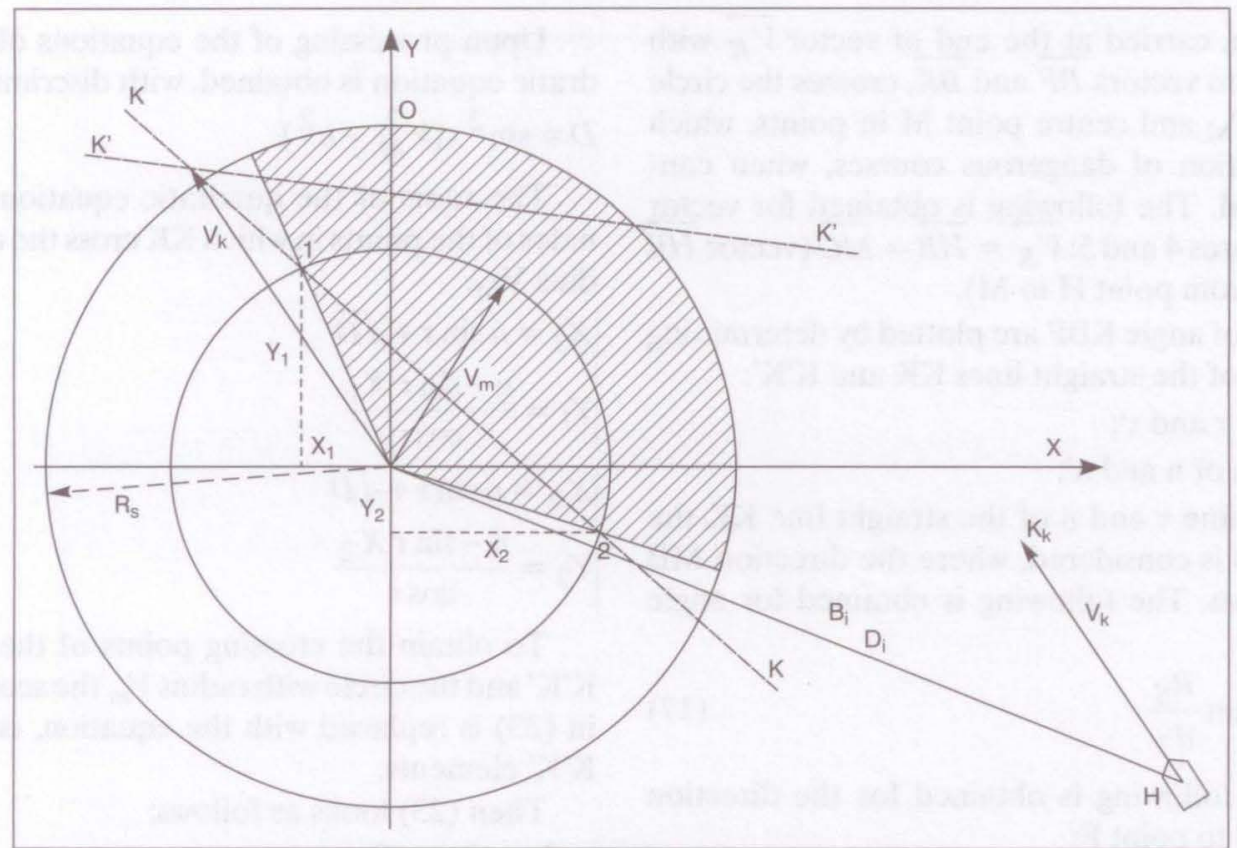

Figure 5 - The section of dangerous courses

\section{Dr. JELENKO ŠVETAK}

E-mail: jelenko.svetak@fpp.uni-lj.si

Univerza v Ljubljani, Fakulteta za pomorstvo in promet Pot pomorščakov 4, 6320 Portorož, Republika Slovenija

\section{POVZETEK}

\section{OCENA NAVIGACIJSKE VARNOSTNE ZONE}

Navigacijska varnostna zona okoli ladje je bila predmet raziskovanja mnogih avtorjev. Predlagani so bili različne variante in algoritmi in sicer:

- varnostna zona okoli ladje naj bi se opazovala s pomočjo lastnih naprav, ki bi informacijo o morebitnem trčenju neposredno prikazali na poveljniškem mostu;

- varnostna zona okoli ladje, ki pluje v shemah ločene plovbe, bi se lahko nadzorovala s pomočjo VTS sistema;

Članek predlaga algoritem za določevanje in vrisovanje navigacijske varnostne zone z naslednjimi prednostmi:

- algoritem nam ponuja takojšno rešitev problema izogibanja ene ali več ladij oz. eho signalov na ARPA (avtomatično grafično plotiranje) sistemu;

- račun lahko uporabi ARPA algoritem, kar pa ne more osvoboditi navigacijskega častnika od vodenja navigacijske straže

Omenjeni algoritem dopušča sočasno grafično vrisovanje dveh pomembnih informacij in sicer: situacije okoli ladje ter verjetno manevriranje.

\section{KLJUČNE BESEDE}

varnost plovbe, ARPA, domena ladje, izogibanje trčenj na morju

\section{LITERATURE}

[1] Švetak, J., Jakomin, L.: Model of Optimal Collision Avoidance Manouevre on the Basis of Electronic Data Collection, Promet-Traffic-Traffico, Vol. 17, No. 6, 2005, pp. 295-302

[2] Баскин, А., Москвин Г.: Береговые системы управления движсением судов, М. Транспорт, 1986

[3] Koburger, C. W., Jr., Vessel Traffic Systems, Cornell Maritime Press/Tidewater Publishers, Centreville MD, 1986

[4] Rosa L. C., Walter F. J., Predicted Area of Danger in Vessel Traffic Services, National Technical Meeting Proceeding, 1999 , pp. $515-526$

[5] Zec, D.: Upravljanje plovidbom u područjima križanja plovidbenih pravaca, P. H. thesis, University of Rijeka, Rijeka, Croatia, 1994

[6] Goodwin, E. M.: A Statistical Study of Ship Domains, The Journal of Navigation, Vol. 28, No. 2, 1975, pp. 328

[7] Švetak, J.: A Model for the Optimal Manoeuvres to Avoid Collision at Sea Based on Electronic Data Collecting, $\mathrm{Ph}$. D. thesis, University of Ljubljana, Portorož, Slovenia, 2002 